\title{
伝統的設計技術における屋根勾配と平面寸法 ベトナム中部の伝統家屋の設計技術の特質（その 1 ) \\ THE RELATIVITY OF THE ROOF PITCH PLANING WITH THE DIMENSIONAL PLAN ON THE TRADITIONAL DESIGN METHODOLOGY
}

Study on the design methodology of the traditional wooden houses in the central Vietnam I

\author{
林＼cjkstart英昭*, 中川 武**, レ・ヴィン・アン*** \\ Hideaki HAYASHI, Takeshi NAKAGAWA and Vinh An LE
}

\begin{abstract}
The architectural differences between Northern and Middle-Southern Vietnam are based on the method for the roof pitch planning. The Northern method is based on the horizon, vertical line and the dimensional unit, the roof line is designed by the horizontal dimension and the height. The Middle-Southern method is not based on the horizon, vertical lines, the plan designed by concrete dimensions, and the roof line fixes one hypotenuse unit as 2 height units. The points are namely the difference of the main design tools, the square tool and the equilateral triangle tool, those can be considered as a gap of the traditional architectural technique and culture between two regions.
\end{abstract}

Keywords : Central Vietnam, Hue, Traditional Houses, Carpentry Works, Design Methodology, Roof Pitch Planning ベトナム中部，フ工，伝統家屋，大工技術，設計技術，屋根勾配

\section{1. 研究の概要}

1-1. はじめに

本研究はベトナム中南部地域に分布する登り梁ケオ【Kèo】で屋根を 支える伝統家屋を対象に，その設計技術の特質を明らかにすることを目 的としている. 登り梁ケオを持つ伝統木造建築の架構が，ベトナム北部 に分布する重㱛梁や束を主構造とする伝統木造建築と異質であることは 既に多くの指摘があるが，その相異の背景にある設計技術についての具 体的な研究は未着手の分野である。 まず本稿ではベトナム中部の大工棟 梁を主な対象として行ってきた調査に基づき，ベトナム北部の設計技術 の事例と比較することで，フエの伝統家屋の梁行架構の設計技術につい てその特質を明らかにしたい. 本研究は現在の大工が保持している技術 から，双方の設計技術の特質を具体的に整理することで，技術史上の影 響関係について遡行的に腑分けしょうという試みである。

\section{1-2. 北部と中南部の建築的相異と共通点}

ベトナム北部（以下, 北部）の伝統木造建築とベトナム中南部（以下, 中南部) に残るそれの架構型式の相違点は，おおよそ以下のように整理

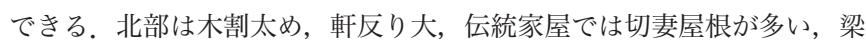
行架構は重孩・束・登り梁ケー【Kẻ】の組合せ，大梁が柱や大斗上 に載り, 架構を軸組と小屋組に二分できる。一方で, 中南部は木割細め, 軒反り小, 入母屋屋根が多く, 梁行架構は登り梁ケオと柱を中心に構成 され，大貫チェン【Trến】が柱中段を貫き，軸組と小屋組に分けられな い一体型の架構とする。一方で両地域の共通点として, 平面の前後左右 対称性，同一地域内であれば大規模から中小規模の建築までよく似た架 構型式が見られる点，柱が梁行方向に内転びを持つ点，正面性の重視な
ぞが挙げられる。本研究はこうした相異や共通点の背景を，それぞれの 設計技術に基づいて説明しようという意図を持って進められた。

\section{1-3. 既往研究}

管見の限り，ベトナム建築の設計技術について具体的に採り上げた研 究はこれまでのところほとんど無い，文書としての設計技術書が未発見 であると同時に未だ大工仕事が学術的研究の対象として評価を受けてい ないことも一因と思われる，無論，ベトナムの伝統家屋そのものに関 する研究や報告は 20 世紀前半のフランスの研究者にまで遡る ${ }^{1)}$. 近年 では, Quế Hà (2005) ${ }^{2)}$ においてべトナム全土における伝統家屋の地 域毎の特徵と相互の影響関係の整理が試みられた。これは 1997 年から 2002 年にかけてべトナム 10 省を対象として行われた伝統家屋に関す る調査結果に基づいている ${ }^{3)}$. また大山 $(2004,2008)^{4)}$ によりべトナ ム北部の寺院の架構型式の分類に基づいて，その史的変遷の過程が整理 された，Quế Hà, 大山両氏の研究はいずれも現存する遺構の実測調査 を基礎としている ${ }^{5)}$.これらの研究の一部として部材名称や遺構の実測 寸法についていくつかの分析があるものの，具体的な設計技術の解明に は至っていない.

本研究はそうした既往の研究成果を充分に参考にしながら，それらを 発展的に補うために, 現在の大工棟梁の有する伝統的技術を整理し, 北 部と中南部の技術的な関連性や建築史的な経緯について遡行して考察す る。そ扎らを踏まえた上で改めて実際の遺構を検証することで，より確 かな実態に近づくことができると考える.

\section{1-4. 研究目的}

本研究は (1) 登り梁ケオを主構造とするベトナム中南部特有の架構

\footnotetext{
* 早稲田大学理工学術院 客員講師・修士 (工学)

***早稲田大学理工学術院教授・博士(工学)

*** フエ遺跡保存センター 技術職員・博士(工学)
}

Visiting Lecturer, Faculty of Science and Engineering, Waseda University, M. Eng.

Prof., Faculty of Science and Engineering, Waseda University, Dr. Eng. Technical Staff, Hue Monuments Conservation Centre, Dr. Eng. 


\begin{tabular}{|c|c|c|c|c|c|c|c|}
\hline 氏名 & (主な仕事) & (都市名 ·地域) & $\begin{array}{l}\text { 生年 } \\
\text { (年齢) }\end{array}$ & 経験年数 & $\begin{array}{l}\text { 修業期間 } \\
\text { (年齢) }\end{array}$ & $\begin{array}{l}\text { 祖父の職業 } \\
\text { (主な仕事) }\end{array}$ & $\begin{array}{l}\text { 父の職業 } \\
\text { (主な仕事) }\end{array}$ \\
\hline レ・キム・タン & Thợ Tuồng Trò & $\begin{array}{r}\text { Thủy Phù, Hương Thủy, TT-Huế } \\
\text { (フエ・中部) }\end{array}$ & $\begin{array}{c}1940 \\
(68)\end{array}$ & 51 & $\begin{array}{c}1955-1957 \\
(15-17) \\
\end{array}$ & Thầy Đồ Nho & Nông Dân \\
\hline $\begin{array}{l}\text { Châu Văn Điền } \\
\text { チャウ・ヴァン・ディエン }\end{array}$ & \begin{tabular}{|c|} 
Thợ Tuồng Trò / Chạm \\
Nhà, Chùa \\
\end{tabular} & $\begin{array}{r}\text { Thủy An, TP. Huế, TT-Huế } \\
\text { (フエ・中部) }\end{array}$ & $\begin{array}{l}1926 \\
(82)\end{array}$ & 51 & $\begin{array}{c}1934-1957 \\
(8-31)\end{array}$ & $\begin{array}{c}\text { Thợ Tuồng Trò } \\
\text { (Nhà Gố, Nhà Tre) }\end{array}$ & $\begin{array}{l}\text { Thợ Tuồng Trò } \\
\text { (Nhà, Chủa, Đình) }\end{array}$ \\
\hline グエン・レー & Thợ Tuồng Trò & $\begin{array}{r}\text { Hương Vân, Hương Trà, TT-Huế } \\
\text { (フエ・中部) }\end{array}$ & $\begin{array}{l}1947 \\
(61)\end{array}$ & 32 & $\begin{array}{l}1966-76 \\
(19-32)\end{array}$ & $\begin{array}{c}\text { Thợ Tuồng Trò } \\
\text { (Nhà Tre, Nhà Rội) }\end{array}$ & $\begin{array}{c}\text { Thợ Tuồng Trò } \\
\text { (Nhà Gỗ, Nhà Rường) }\end{array}$ \\
\hline $\begin{array}{l}\text { Lê Viết Tám } \\
\qquad \text { レ・ヴィエット・タム }\end{array}$ & Thợ Tuồng Trò & $\begin{array}{r}\text { Cẩm Nam, Hội An, Quảng Nam } \\
\text { (ホイアン・中部) }\end{array}$ & $\begin{array}{l}1956 \\
(52) \\
\end{array}$ & 36 & $\begin{array}{c}1968-72 \\
(12-16)\end{array}$ & Thợ Tuồng Trò & $\begin{array}{l}\text { Thợ Tuồng Trò / Đâu } \\
\text { (Nhà) }\end{array}$ \\
\hline $\begin{aligned} & \text { Lê Văn Thê } \\
& \text { レ・ヴァン・テー } \\
&\end{aligned}$ & \begin{tabular}{|l|} 
Thợ Tuồng Trò \\
Nhà, Đình, Chùa, Cung Điện
\end{tabular} & $\begin{array}{r}\text { Đức Lý, Lý Nhân, Hà Nam } \\
(\text { ハーナム・北部) }\end{array}$ & $\begin{array}{l}1965 \\
(43) \\
\end{array}$ & 22 & $\begin{array}{l}1982-86 \\
(17-21) \\
\end{array}$ & $\begin{array}{l}\text { Thợ Tuồng Trò } \\
\text { (Nhà, Đình) }\end{array}$ & $\begin{array}{l}\text { Thợ Tuồng Trò } \\
\text { (Nhà, Đình) }\end{array}$ \\
\hline $\begin{array}{c}\text { Phan Trinh Thám } \\
\text { ファン・チン・タム }\end{array}$ & \begin{tabular}{|c|} 
Thợ Tuồng Trò / Đâu \\
Nhà, Chùa
\end{tabular} & $\begin{array}{r}\text { Thủy Vân, Hương Thủy, TT-Huế } \\
\text { (フエ・中部) }\end{array}$ & $\begin{array}{l}1968 \\
(40)\end{array}$ & 22 & $\begin{array}{l}1983-86 \\
(15-18) \\
\end{array}$ & Thợ Tuồng Trò & - \\
\hline
\end{tabular}

表註：Thợ Tuồng Trò / 大工, Thợ Tuồng Chạm / 彫師, Thợ Tuồng Đâu / 家具職人, Nhà / 家屋, Chùa / 寺, Đình / ディン, Cung Điện / 宮殿, Thầy Đồ Nho / 儒家, Nông Dân / 農民 表 2 制作模型の種類と仕様

\begin{tabular}{|c|c|c|c|c|c|c|c|}
\hline No. & 模型呼称 & 大工棟梁 & 地域 & 規模 & 種別 & 棟下の型式 & 登り梁の型式 \\
\hline 01 & Nhà 4.2 & \multirow{3}{*}{ Lê Kim Tân } & \multirow{3}{*}{ フエ } & Nhà 4.24 / 3 gian 2 chái kép & Nhà Thợ & Trụ tiêu-Con đội-Áp qủa & Kèo Chồng \\
\hline 02 & Nhà 3.8 & & & Nhà 3.8 / 3 gian 2 chái kép & Nhà ở & Rầm Thượng & Kèo Luông \\
\hline 03 & Nhà 3.2 & & & Nhà $3.2 / 1$ gian 2 chái kép & Nhà ở & Rầm Thượng & Kèo Luông \\
\hline 05 & Nhà 4.6 & Nguyễn Rê & フエ & Nhà 4.6 / 3 gian 2 chái kép, Mái Hiên & Nhà Thợ & Tôm bụp-Độc bình-Cánh quạt & Kèo Hàng Tứ \\
\hline 06 & Nhà $1.79 \mathrm{~m}$ & Lê Viết Tam & ホイアン & Nhà $1.79 \mathrm{~m} / 3$ gian 2 Hè dục & Nhà Đấm Quyết & Con Dơi-Trái Bí-Dép Đế & Kèo Lòng Tứ \\
\hline 07 & Đình Văn Xá & Lê Văn Thê & ハーナム & Đình Thượng Tứ-Hạ Ngũ / 3 gian 2 hồi & Đình Bắc Bộ & Vì Nóc/Câu Đầu-Con Chồng-Trụ Non & Kẻ Liền, Hồi \\
\hline 08 & Nhà 3.6 & Phan Trinh Thám & フエ & Nhà 3.6 / 3 gian 2 chái kép, Mái Hiên & Nhà ở & Rầm Thượng & Kèo Luông/Kèo Hai Loại \\
\hline
\end{tabular}

表註 : 規模表記や架構型式, 部材名称等の記法については「3. 中部の伝統木造建築の設計方法」掞よび図 5 を参照

型式の特徴をその設計技術を通じて具体的に解明すること，(2) ベト ナム北部の架構型式との相異を設計技術の相異として具体的に裏付ける ことを目的とする．前項で触れた Quế Hà (2005) や大山 (2004,2008) は，いずれも遺構の分析から建築の発展経過に迫るものであった。特に 架構の類型化や柱間寸法分析等を駆使して架構型式の発展経過や年代推 定に至る論証は，大筋で納得性の高いものであり，ベトナムの建築史研 究へ初めて積極的に工学的な視点を持ち込んだ点で画期的であったと 言える。一方で遺構から推測できることは限られており，上記目的の 2 点については未だに言及がないと考える.

\section{1-5. 研究方法}

本研究は伝統家屋の設計・施工が可能な大工棟梁に縮尺 $1 / 5$ の模型制 作を依頼し，制作作業と並行してその設計技術を聴取するという方法で 行われた。具体的な模型を介して双方の意思踈通に利を図った方法であ る。墨打ちの板図，型板，間笔，各制作部材のスケッチ，写真による記 録に加え, 各工程をビデオ撮影し，工具の使用法や部材の加工手順など 制作の様子を映像記録として残すように努めた。

本稿では 2004 年 6 月から 2008 年 3 月にかけて行った計 6 組（模型 8 棟）の大工棟梁に対する調査結果を分析の対象とし, その成果の一部 として, 屋根勾配と柱間寸法の決定方法を中心に比較考察を行う（表 1 , 表 2) ${ }^{6)}$. 本稿は主に梁行架構の設計技術を対象とした。ベトナムの伝 統木造建築は全土に共通して, 平面計画において前後・左右に強い対称 性を持ち，桁行は同規格で構成された梁行架構を建て並べることで空間 を成す，入母屋造り屋根の妻側の架構も梁行架構がそのまま展開される 場合が多く，建築の全体が一筋の梁行架構を基本としていることは明ら かである ${ }^{7)}$. また梁行架構の相異は屋根を支える手法の違いであり, 建 築の成立する技術的背景の相異が想定できる.

よってまずは梁行架構の相異に注目することで，北部と中南部の建築 的特徵の相異が具体化すると考えた。本研究の進展の先には中華圏と南 方周辺地域との文化間相互の影響関係を建築の設計技術の比較分析に基 づいて指摘したいという見通しがある.

また本研究では中南部の設計技術を代表するものとしてべトナム中部 (以下，中部）の伝統木造建築を取り上げ分析の対象とした。ベトナム 南部 (以下, 南部) のそれについては具体的に取り上げていない。登り 梁を中心とした特徵的な架構がどこに起源を求められるかという課題に
は，南部の伝統木造建築の分析が不可欠と予想しているが，本稿ではま ず北部と中部の相異を具体的に位置づけ明確に腑分けすることを重視し た。そうした位置づけを踏まえた後，南部の設計技術について分析を進 めることで, 改めてべトナム全土の建築的特徵が具体的に浮上してくる ものと考える.

\section{2. 北部の伝統木造建築の設計技術}

北部の設計技術の例として，北部のディン【Đình】 ${ }^{8)}$ の設計技術を知 る大工棟梁を対象に聞き取り調査を行った結果を整理する。調査は北部 出身の大工棟梁であるレ・ヴァン・テー【Lê Văn Thê】氏 ${ }^{9)}$ (以下, Thê 氏) にハーナム省に現存するディン・ヴァン・サー【Đình Văn Xá】 ${ }^{10)}$ の縮 尺 $1 / 5$ 模型の制作を依頼して行われた。以下，梁行架構の設計手順につ いて分析する (以下本節の寸法値は縮尺 $1 / 5$ 模型の寸法).

2-1. 北部の梁行架構の設計技術

梁行架構の設計の基本線の墨打ち順序を, 図 1 に番号で示した ${ }^{11}$. 概して以下の手順に沿って進められる (以下, 丸番号は図 1 と対応).

1) 水平線と鉛直線（地盤線と梁行中心線）：(1) - (2)

2) 主柱高さ：(3)

3）各柱間寸法（柱元にて中央 $=8 \mathrm{~A}$, 前後 $=5 \mathrm{~A}$ )

4）主柱内転び（柱頂部にて各 10mm）：(4)-(5)

5）屋根勾配（チア・コハン・ホアンに準拠）：(6)

6) ヒエン柱高さ・内転び（柱頂部にて各 $7 \mathrm{~mm}$ ) : (7) - (8) - (9)

7）母屋桁の配置（柱頂部にて中央間 $=8 \mathrm{~B}_{1}$, 前後 $=5 \mathrm{~B}_{2}$ )

8) 各部材の輪郭, 断面の描画

基準となる水平線と鉛直線を最初に確定し, 次いで高さ, 柱間（転び）, 屋根勾配という設計手順である，以下にその要点を整理する。

1）基準単位の決定

設計に先立って，まずはチア・コハン・ゴック【Chia Khoảng Gốc】 という設計上の単位となる直角三角形を決定する (図 1 左下)。底辺を チア・コハン・ガン【Chia Khoảng Ngang】, 垂線をチア・コハン・ドゥ ン【Chia Khoảng Đứng】, 斜辺をチア・コハン・ホアン【Chia Khoảng Hoành】と呼ぶ。一単位が母屋桁間距離一つ分となるのが原則であり, 同時に柱間寸法決定の基準単位ともなる。斜辺を屋根勾配とし，底辺： 垂線 $=3: 2$ 程度が一般的で, 屋根葺き材の種類によっては $100: 75$ など例外もあるという。こうした直角三角形の底辺と垂線を設計の基準 
とする設計方法に付随して，トゥオックサーム【Thước Sàm】と呼ばれ る L 字型の尺（写真 1) が墨付けの道具として用いられる. 現在まで北 部 5 省でこれを使用する大工集団を確認している. 今回は Thê 氏によ るディン・ヴァン・サーの実測に基づいて縮尺 $1 / 5$ 模型の寸法で底辺： 垂線：斜辺 $=100 \mathrm{~mm}: 66 \mathrm{~mm}: 120 \mathrm{~mm}$ として設計を行った ${ }^{12)}$.

2) 母屋林の配置

母屋桁の配置は原則として最初に決定したチア・コハン・ゴックを基 準単位とする。しかしながら上記設計手順の 3) のように柱元をチア・ コハン・ゴックの倍数で設定する以上，柱内転びのため柱頂部が狭くな るため, 自ずと母屋桁間距離は最初に決定したチア・コハン・ゴックよ り小さくなる.

図 1 中では最初のチア・コハン・ゴックを A (100mm) とし，第一 間の柱頂部を等間で割ったチア・コハンを $\mathrm{B}_{1}$, 第二間を等間で割った チア・コハンを $\mathrm{B}_{2}$ として示した。計算上はコハン・ガン $\mathrm{B}_{1}=780 \div 8$ $=97.5 \mathrm{~mm}$ ，コハン・ガン $\mathrm{B}_{2}=503 \div 5=100.6 \mathrm{~mm}$ となる.ここで Thê氏氏はう一種類チア・コハンを増やし，それぞ第一間，第二間， 軒先用とした。若干の䛊差はあるものの, 基本的に屋根勾配を各間とも 同一に保つように設定されている。またここで決定された母屋桁の配置 基準線は特に第一間では大梁上に載る板状の部材ダウ・セン【Đấu Sen】 や束状の部材チュウ・ノン【Trụ Non】の中心線として使用する.

3）登り梁ケーの設計

登り梁ケーの設計技術の要点を図 2 に整理した。基準となるケーの

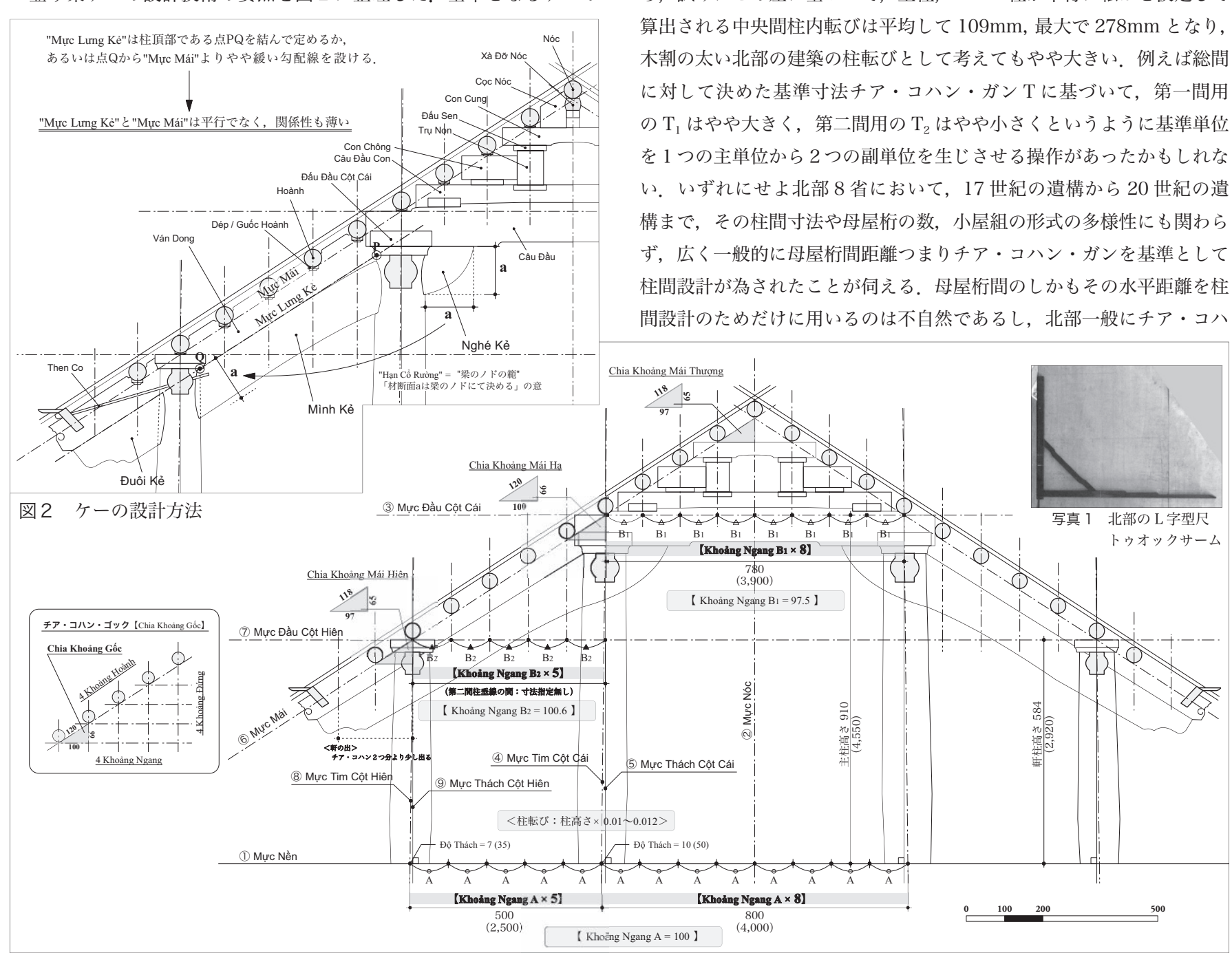

図 1 レ・ヴァン・テー氏による北部のディンの梁行架構の設計方法（寸法值は縮尺 $1 / 5$ 模型の数值。括弧内寸法值は実物大寸法值）
背の線ムック・ルン・ケー【Mực Lưng Kẻ】を描画する際には (i) 柱頂部 (点 $\mathrm{PQ}$ ) を結ぶか, あるいは (ii) 点 Q から屋根勾配線（ムック・マイ） よりやや緩い勾配線を設けるかのどちらかの方法で決定する。いずれに せよ, 屋根勾配の線とはほぼ無関係にケーの勾配が決められる。

\section{2-2. 実遺構における母屋桁配置と柱間寸法}

以上，述べてきた Thê 氏の設計技術の妥当性について検証するため に，その要点である母屋桁の間の数と柱間寸法の関連性について，大山 (2004, 2008) に発表された北部の仏教寺院遺構の実測数值と母屋桁数 に基づいて表 3 へ整理した。 母屋桁間の数について梁行第一間（中央） 半分を「上」, 第二間（前後）を「下」とし，上下それぞれのチア・コハン・ ガンを算出した ${ }^{13)}$. ディン・ヴァン・サーは「上四下五」となる.

Thê氏氏によればディンの母屋桁間の数は「上四下五」 ${ }^{14)}$ という数が 一般的ということであったが, 遺構より確認できるその数は多様である. 大山（2008）では仏教寺院においては時代が下るほど母屋桁数が増え るという指摘もされている. 表 3 の通り,梁行第一間(中央) と第二間(前 後) の間のチア・コハン・ガンには明らかな差異が認められる。ほとん ぞの遺構において中央間のそれが $5 / 100$ 程度大きい. 全体の傾向とし ては梁行三間の計画が同一の単位寸法を前提とした, 換言すればチア・ コハン・ガンに基づいて為されたと認めて良いと思われるが，一方で， 母屋桁間が梁行中央で 8 間前後, 5/100 の差が 8 倍になると考えると, 計画上は無視できない值となる，実測值は柱元での值のようであるか ら, 試みにこの差に基づいて, 主柱, ヒエン柱が平行に転ぶと仮定して 算出される中央間柱内転びは平均して $109 \mathrm{~mm}$, 最大で $278 \mathrm{~mm}$ となり, 例えば総間 を1つの主単位から $2 つ の$ 副単位を生じさせる操作があったかもしれな い.いずれにせよ北部 8 省において，17 世紀の遺構から 20 世紀の遺 構まで，その柱間寸法や母屋桁の数，小屋組の形式の多様性にも関わら ず，広く一般的に母屋桁間距離つまりチア・コハン・ガンを基準として 住間設計が為されたことが伺える．母屋桁間のしかもその水平距離を柱 間設計のためだけに用いるのは不自然であるし，北部一般にチア・コハ hia 
表 3 北部の仏教寺院におけるチア・コハン・ガンの寸法

\begin{tabular}{|c|c|c|c|c|c|c|c|c|c|c|}
\hline \multirow[t]{2}{*}{ 遺構名 } & \multirow[t]{2}{*}{ 推定年代 } & \multirow[t]{2}{*}{ 所在地 } & \multicolumn{3}{|c|}{ 梁行柱間寸法 $(\mathrm{mm})$} & \multicolumn{2}{|c|}{ 母屋桁間の数 } & \multicolumn{3}{|c|}{ チアコハンガン $(\mathrm{mm})$} \\
\hline & & & 前 & 中央 & 後 & T & 上 & 前 & 中央 & 後 \\
\hline 香齊寺上殿 & 14-16c. & HT 省 & 1,476 & 3,081 & 1,302 & 3 & 3 & 492 & 514 & 434 \\
\hline 大悲寺上殿 & 14-16c. & HT 省 & 1,423 & 3,397 & 1,397 & 3 & 3 & 474 & 566 & 466 \\
\hline ND 省神光寺開祖堂 & 17c. 前 & ND省 & 1,262 & 2,501 & 1,167 & 4 & 4 & 316 & 313 & 292 \\
\hline TB 省神光寺上殿 & 17c. 前 & TB省 & 1,588 & 3,417 & 1,639 & 4 & 4 & 397 & 427 & 410 \\
\hline TB 省神光寺開祖堂 & 17c. 前 & TB 省 & 2,036 & 3,113 & 1,857 & 4 & 3 & 509 & 519 & 464 \\
\hline 寜福寺上殿 & 17c. 中 & BN 省 & 2,056 & 3,387 & 2,045 & 4 & 3 & 514 & 565 & 511 \\
\hline 天福寺上䐩 & $17 \mathrm{c}$. & HT省 & 2,764 & 5,883 & 2,967 & 4 & 4 & 691 & 735 & 742 \\
\hline 息山寺上殿 & $17 \mathrm{c}$. & HD 省 & 2,171 & 4,468 & 2,194 & 3 & 3 & 724 & 745 & 731 \\
\hline 法雲寺上殿 & 14-16c. & HY 省 & 1,978 & 4,081 & 1,617 & 3 & 3 & 659 & 680 & 539 \\
\hline 大悲寺開祖堂 & 17c. 後 & HT 省 & 709 & 2,213 & 686 & 2 & 3 & 355 & 369 & 343 \\
\hline 延應寺上殿 & 14-16c. & $\mathrm{BN}$ 省 & 1,957 & 4,073 & 1,959 & 3 & 3 & 652 & 679 & 653 \\
\hline $\begin{array}{l}\text { 金蓮寺上殿 } \\
\end{array}$ & 18c. 後 & HN 市 & 1,662 & 2,690 & 1,665 & 4 & 3 & 416 & 448 & 416 \\
\hline 西方寺上殿 & 18c. 後 & HT 省 & 1,603 & 2,668 & 1,596 & 4 & 3 & 401 & 445 & 399 \\
\hline 永籗寺上殿 & 20c. 前 & BG 省 & 2,023 & 3,919 & 1,983 & 5 & 5 & 405 & 392 & 397 \\
\hline 永厳寺開祖堂 & 20c. 前 & BG 省 & 1,478 & 2,401 & 1,515 & 4 & 3 & 370 & 400 & 379 \\
\hline 廣敩寺上殿 & 20.c 前（改修） & HT 省 & 1,924 & 3,106 & 1,833 & 5 & 4 & 385 & 388 & 367 \\
\hline 普明寺上殿 & 20c. 前 (再建) & ND省 & 2,285 & 4,055 & 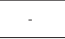 & 6 & 5 & 381 & 406 & . \\
\hline 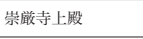 & 20c. 前 (再建) & HT 省 & 1,409 & 2,988 & 1,456 & 4 & 4 & 352 & 374 & 364 \\
\hline 撖光寺上殿 & (不詳) & HD 省 & 1,281 & 2,398 & 1,254 & 3 & 3 & 427 & 400 & 418 \\
\hline
\end{tabular}

ンを用いた屋根勾配の制御が行われてきたと考えるのが妥当であろう. また Nguyễn Khắc Tụng (1994) ${ }^{15)}$ において，北部の伝統家屋の設計技 術の基本として「(1) 梁行三間を 10 等分し，4 分を中央，各 3 分を前 後の柱間へ割り当てる」あるいは「(2) 梁行三間を 18 等分し, 8 分を 中央，各 5 分を前後の柱間へ割り当てる」という技術が紹介され， L 字 型の道具についても言及されている。これは本稿で言う「上二下三」と 「上四下五」の型式に相当する設計技術を示したものと思われる，Quế Hà, 山田 (2000) ${ }^{16)}$ ではこの知見を基に北部バクニン省の伝統的民家 47 棟の 4 種の架構型式に分類し，それぞれの型式毎に柱間寸法を平均 化して分析を行っており，いずれも（2）の「上四下五」の説とほぼ同 じ比率関係が成り立つことを指摘している，北部の伝統家屋においても 遺構に同様の設計技術が見られることが裏付けられたと言えるが，同稿 に揭載された梁行断面図面には「上三下四」が多く, 同省の伝統家屋は 必ずしも「上四下五」では無い点は留意すべきである.

\section{2-3. 北部の設計技術の特徵}

\section{1) 水平線と鉛直線を前提とした設計技術}

北部の設計技術は原則として水平線と鉛直線を基準として設計され る. 特にチア・コハンという基準単位の設定は, 平面計画と屋根勾配の 決定を一つの道具（トゥオックサーム）に集約する意図を持つ. 本来こ れは水平梁と束など水平・鉛直材のみで主構造を構成する場合に各部材 の材積計算の容易さなど多くの便宜があっただろう.Quế Hà (2005) や大山（2008）で指摘されているチュウ・ノンやダウ・センと呼ばれ る部材の配置が, 北部における多くの遺構で各母屋桁の直下を踏む点も, チア・コハンに基づいた設計の結果と言え，本節で採り上げた設計技術 が北部の伝統木造建築において広く一般性のある技術と推測できる.

また登り梁ケーが掛かる柱間においても同様にチア・コハンが柱間を 決定しており, 更にはケーの墨が屋根勾配とは無関係に成立する点は, ケーがこの勾配制御の技術とは無関係に成立していることを示すと考え られる. 実際に正面三間で同寸の梁行架構を 4 筋持つ遺構においても中 央間にケー, 脇間に重㱛梁を持つ遺構が度々確認されることも同様の解 釈が可能であろう ${ }^{17)}$. 恐らくチア・コハンを利用した設計技術は重称 梁と束など水平・鉛直材のみで構成された，ケーを持たない架構を前提 とした技術である. 大山（2008）によれば，ケーを持つ遺構は既に 17

\begin{tabular}{|c|c|c|c|c|c|c|c|c|c|c|}
\hline \multirow[t]{2}{*}{ 遺構名 } & \multirow[t]{2}{*}{ 推定年代（大山） } & \multirow[t]{2}{*}{ 所在地 } & \multicolumn{3}{|c|}{ 梁行柱間寸法 $(\mathrm{mm})$} & \multicolumn{2}{|c|}{ 母屋桁間の数 } & \multicolumn{3}{|c|}{ チアコハンガン $(\mathrm{mm})$} \\
\hline & & & 前 & 中央 & 後 & 下 & 上 & 前 & 中央 & 後 \\
\hline 天福寺前堂 & $17 \mathrm{c}$. & HT 省 & 1,544 & 2,621 & 1,535 & 4 & 3 & 386 & 437 & 38 \\
\hline $\mathrm{TB}$ 省神光寺前堂 $\mathrm{c}$ & 17c. 前 & TB 省 & 1,983 & 3,167 & 2,019 & 4 & 3 & 496 & 528 & \\
\hline TB 省神光寺前堂 $b$ & 17c. 前 & TB 省 & 1,842 & 3,257 & 1,807 & 4 & 3 & 461 & 543 & 45 \\
\hline 寜福寺前堂 & 17c. 前 & BN 省 & 2,118 & 3,379 & 2,136 & 4 & 3 & 530 & 563 & 534 \\
\hline 法雨寺前堂 & 17c. 前 & HT 省 & 1,498 & 2,560 & 1,557 & 4 & 3 & 375 & 427 & \\
\hline 崇厳寺前堂 a & 17c. 前 & HT 省 & 1,575 & 3,203 & 1,578 & 3 & 3 & 525 & 534 & 52 \\
\hline$N D$ 省神光寺前堂 $b$ & 17c. 後-18c. & ND省 & 1,490 & 2,405 & 1,573 & 4 & 3 & 373 & 401 & 393 \\
\hline 金蓮寺前堂 & 18c. 末 & HN 市 & 1,286 & 2,484 & 1,388 & 4 & 3 & 322 & 414 & 34 \\
\hline 西方寺前堂 & 18c. 末 & HT 省 & 1,524 & 2,231 & 1,428 & 4 & 3 & 381 & 372 & 357 \\
\hline TB 省神光寺前堂 $\mathrm{a}$ & 18c. 末 & TB 省 & 2,447 & 3,623 & 2,419 & 4 & 3 & 612 & 604 & 60 \\
\hline 廣䇴寺前堂 & 18c. 末 & HT 省 & 1,579 & 3,227 & 1,616 & 4 & 4 & 395 & 403 & 40 \\
\hline 崇葳寺前堂 b & 19c. 中 & HT 省 & 1,469 & 2,500 & 1,597 & 5 & 4 & 294 & 313 & 31 \\
\hline 福林寺前堂 & 19c. & ND 省 & 1,401 & 2,249 & 1,425 & 4 & 3 & 350 & 375 & 35 \\
\hline $\mathrm{ND}$ 省神光寺前堂 $\mathrm{a}$ & 19c. 後-20c. 前 & ND 省 & 1,623 & 2,273 & 1,594 & 4 & 3 & 406 & 379 & 39 \\
\hline 挺蘭寺前堂 & 19c. 後-20c. 前 & ND省 & 981 & 2,068 & 964 & 3 & 3 & 327 & 345 & 32 \\
\hline 永厳寺前堂 b & 19c. 後-20c. 前 & BG 省 & 1,456 & 2,353 & 1,554 & 4 & 3 & 364 & 392 & 38 \\
\hline 厳光寺前堂 & 19c. 後-20c. 前 & HD 省 & 1,475 & 2,700 & - & 4 & 3 & 369 & 450 & \\
\hline 香斎寺前堂 & 19c. 後-20c. 前 & HT 省 & 1,389 & 2,957 & 1,270 & 3 & s & 463 & 493 & 423 \\
\hline 延應寺前堂 & 20c. 前 & BN 省 & 1,483 & 3,179 & 1,461 & 4 & 4 & 371 & 397 & 365 \\
\hline 大悲寺前堂 & 20c. 前 & HT 省 & 1,448 & 3,112 & 1,389 & 4 & 4 & 362 & 389 & 347 \\
\hline 㦝山寺前堂 & 20c. 前 & HD 省 & 2,074 & 3,477 & 2,033 & 5 & 4 & 415 & 435 & 407 \\
\hline 法雲寺前堂 & 20c. 前 & HY 省 & 1,745 & 2,625 & 2,036 & 6 & 4 & 291 & 328 & 339 \\
\hline 普明寺前堂 & 20c. 前 & ND 省 & 1,902 & 3,389 & 1,844 & 6 & 5 & 317 & 339 & 307 \\
\hline 永厳寺前堂 a & $20 \mathrm{c}$. 前 & BG 省 & 1,965 & 4,152 & 2,003 & 5 & 5 & 393 & 415 & 401 \\
\hline
\end{tabular}

*大山（2008）表 2 に基づいて再構成。遗栱順，推定年代は同表 4 より。史料，碑文，楝銘などに架構形式等の分類 を含めて考察されている。

**表中グレイ表示はチア・コハンの前後と中央の差が 1 割を超えるもの

世紀の寺院に見られるから，チア・コハンに基づいた設計技術の発生や 伝播はそれ以前に遡ると考えることも可能であろう.

本来，母屋桁間距離を柱間寸法および屋根勾配と関連づける技術は， 例えば中国の反り屋根の技法に見られるような, 本来は母屋桁間毎に勾 配を制御し，屋根の大きな撓み出しに最も有効な技術であると考えられ る.しかし Thê 氏の場合, 屋根勾配の墨は原則直線であり, 施工時に 母屋桁の受け材の深浅で若干の撓みを造り出す程度であるという。大山 (2004，2008）それぞれで対象とされた遺構は古い事例では 17 世紀に まで遡るが，そこに揭載された梁行断面図や架構の写真を見る限り，屋 根に大きな撓みを持つ寺院は無く，母屋桁間毎に勾配を制御したような 形跡は見られない.

2）柱内転びと柱間決定の位置

Thê 氏のチア・コハンを利用した設計技術の理解では柱元で柱間寸法 を指定した。中部では柱上部の大梁位置で柱間寸法を指定するのが原則 である、中部で転びを意味する夕ック【Thách】は「外に開く」という 含意がある、一方, 北部では内転びをトゥー【Thu】と呼び, これは「縮 む/転ぶ」という含意がある。ここには北部は下から，中部は上から設 計を始めるという相異が見てとれる，ただし，Thê氏の設計技術の理解 において, 柱転びを出した後にチア・コハンの種類を増やすという一見 不合理な方法を採った点, なお一考が必要である.

またチア・コハンが屋根勾配を制御する技術の一種であり，この設計 技術があくまで屋根の墨（図 1 中， (6) Mực Mái）に注力している点は明 らかである。屋根勾配と柱間との関係はチア・コハンの決定によって自 ずと決まる，柱転びを生じせしめる柱総高さは, 屋根勾配とは無関係と 言って良い. よって棟木や柱頂部を起点に屋根の墨が引かれた後に, 地 盤面の高さを設定しその後に柱転びを設計する，つまり柱間を上部で決 め, 後に柱元を開く方が一層合理的だと言えよう。ベトナムの伝統木造 建築では梁行方向に柱元を固める部材がほとんど無いことも, 同様の示 唆を与えると考える. よって北部の架構形式においても柱間決定位置は 
柱頂部にある方がより合理的ではある。しかしながら実際の遺構は前述 の通りチア・コハンを柱間毎に変えてふり直したとも解釈できる点, な お一考の余地がある。

\section{3. 中部の伝統木造建築の設計技術}

中部の伝統木造建築の設計技術に関しては，フエで 4 組 6 棟，ホイ アンで 1 組 1 棟の模型制作調査を行った（表 2)。本節では最初にフエ の伝統家屋の架構型式, 設計手順の概要を整理し, 続けてその要点と考 えられる屋根勾配の決定，柱間寸法の決定方法，ドンタイの配置につい てまとめ, それらの意味するところを考えたい，ホイアンの調査で得ら れた結果については，フエとの比較において適宜参照する。また実際の 遺構については適宜 1998 年の全国調査におけるフエの実測図面 (以下, フエ調査 1998） ${ }^{18)}$ を参考にした。

\section{3-1. フエの伝統家屋の型式の種類}

フエにおいて実際に伝統家屋を設計する際に寸法計画に先立って，ま ず決定しなければならないのが，平面規模，ケオの種類，住居か祠堂か の 3 点である.

\section{1) 平面規模の表し方}

フエの伝統家屋の規模は桁行の柱間数で表す。まず桁行方向に見て, 入母屋妻壁の内側の柱間の数を「間【Gian/Căn】」で表し, 妻壁外側を「チャ イ【Chái】」とする。チャイは両側にあるという意味を「2 Chái」と表 し，チャイの間の柱間数を「単【Đơn】」「複【Kép】」「三【Tam】」を付 けて表す。例えば図 3 の平面を持つ家は「3 gian- 2 chái kép」と表現す る。規模を表す際に梁行方向の柱間数は特に言及されない。これは桁行 方向の規模表記が同時に全体規模を含意するほど，梁行方向の種類が限 られることを示している，実際に梁行架構は登り梁ケオに支えられる中 央 3 間（ロン・ニャー【Lòng Nhà,「家の間」の意】と称す）を基本とし, 前後にケオ・クー【Kèo Cù】の間を取った 5 間に, 前庇を加えた例が 圧倒的に多い. フ工調査 1998 では 70 件中, 梁行 5 間に前庇が 61 件, 同庇無し 2 件, 梁行 4 間（後ろのクーの間を略した形式）に庇付が 4 件, 同庇無しが 2 件，梁行 3 間が 1 件．また平面規模は「1 gian- 2 chái」が 13 件 (チャイ：単 $5 /$ 複 8), 「3 gian- 2 chái」が 48 件（同：単 $17 /$ 複 29/三 2), 33 gian- 0 chái」が 8 件, 55 gian- 0 chái 」が 1 件となっている. 2) ケオの種類

梁行架構は柱をケオとチェンで連結して構成される。ケオには棟木か ら各柱間毎に一本ずつ架かる型式と棟木から第一柱を跨いで，第二柱ま でを繋ぐ型式の二種類があり，前者をケオ・チョン【Kèo Chồng，「重 ねケオ」の意】(図 4-1), 後者をケオ・ルオン【Kèo Luông, 「続くケオ」 の意】あるいはケオ・スオット【Kèo Suốt】（図 4-2）と呼ぶ。あるい はケオの数を称して「Kèo 3 loại」,「Kèo 2 loại」や「Kèo 3 Dội」, 「Kèo 2 Dội」と呼び分ける場合もある。両種の使い分けの方法は特に明確では 無いが, フエの Thám 氏からは祠堂はケオ・チョン, 住居はケオ・ルオ ンという話も聞かれた。当然，材の長さと柱間寸法を理由にした使い分 けもあると予想される。 フ工調査 1998 ではケオ・チョンが 16 件, ケオ・ ルオンが 54 件となっている.

\section{3) 住居か祠堂か}

本稿で対象としているフエの伝統家屋は「Nhà Rường Huế」と呼ばれ る往時の貴族，官吏，豪農などの比較的上流階級の邸宅であり，彼ら は邸宅敷地内に住居と同規模の祠堂を持つことが多かったと言われる。 「Nhà Rường」の設計が可能な大工棟梁は即ち住居【Nhà ở】祠堂【Nhà Thờ】の設計が可能である。この点に関して梁行架構の型式は天井を持 つ架構と持たない架構に大別でき，前者は天井裏を備蓄のために活用す

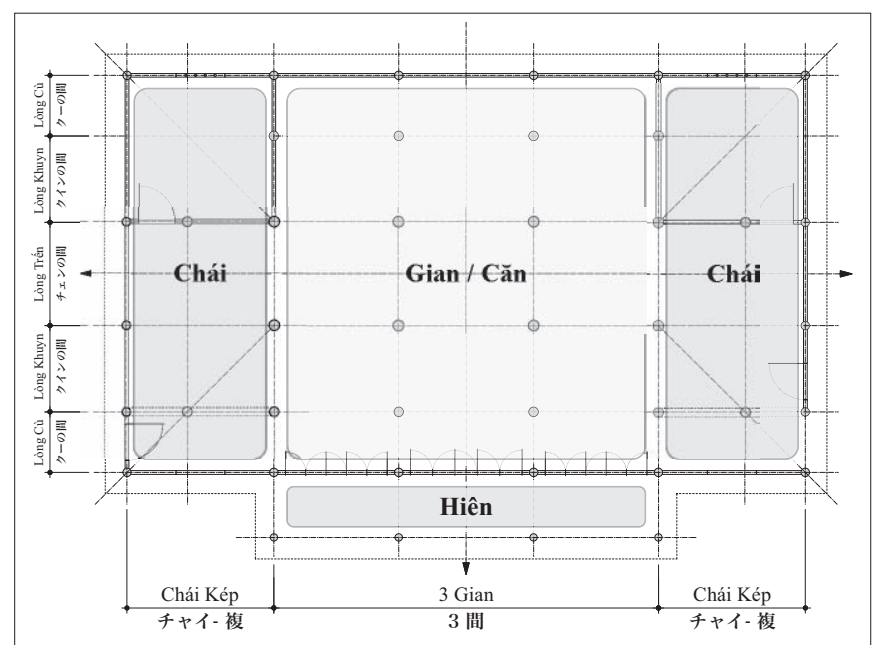

図 3 フエの伝統家屋の平面形式 【3 gian- 2 chái kép】

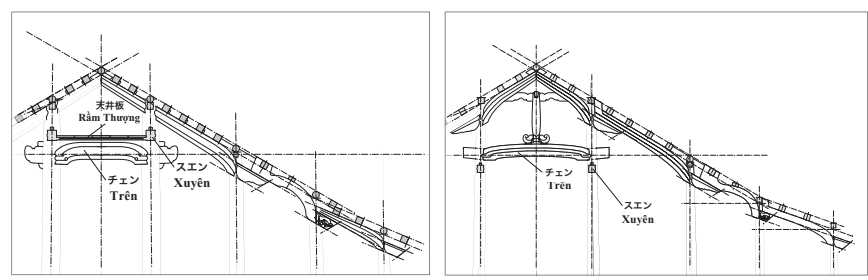

図 4-1（左） フエの伝統家屋の梁行架構型式 A

ケオ・ルオン【Kèo Luông】

上スエンー下チェン【Thượng Xuyên-Hạ Trến】

図 4-2（右） フエの伝統家屋の梁行架構型式 B

ケオ・チョン【Kèo Chông】

上チェンー下スエン【Thượng Trến-Hạ Xuyên】

る住居であり，後者は棟木下に小梁や束を持ち祠堂に適するとされる. 伝統家屋ではスエンが天井板を支えるため, 自ずと天井付きは「上スエ ンー下チェン【Thượng Xuyên-Hạ Trến】」(図 4-1) となり, 天井無しは 束がチェンに載るため「上チェンー下スエン【Thượng Trến-Hạ Xuyên】」 (図 4-2) となるのが基本である. フ工調査 1998 では天井付きが 63 件, 天井無しが 7 件． 圧倒的に天井付きが多いのはこの調査が「民家調査」 と題して住居に注視して進められた結果と考えられる. 天井付きは全て が上スエンー下チェン, 天井無しは町屋の 1 件を除く 6 件いずれも上 チェンー下スエンという架構を持ち, 天井の有無によってチェンとスエ ンの上下関係が明確に定められていることが裏付けられる.

\section{3-2. 設計手順の概要}

実際の設計においては，前項で述べた規模や型式を決定した後，最初 に梁行架構の作図を, 続いて必要であれば平面や桁行断面の作図を行う. 部材の加工に必要な寸法として, 屋根勾配と柱間寸法および柱転びに基 づいて決定される柱とケオの長さと納まりが既知では無いため, 梁行架 構の作図とそこから得られるケオ, チェンなどの型板, 間竿の作成は必 ず必要とされる。一方で両脇チャイの寸法は, 梁行架構で得られた寸法 と同寸か柱の隅伸び等の若干の調整で足り, 桁行横架材は桁行柱間の寸 法と同寸であるから，間竿に寸法を落とすか平面の作図をすることで足 りる。桁行断面の作図の必要性は非常に低い，自ずといずれの大工棟梁 も当然のように梁行架構を非常に重視しており,ここに本稿が梁行架構 を中心に分析を進める理由がある.

以下に梁行架構の作図順序を整理する (丸番号は図 5 と対応).

1) 屋根勾配【Mực Mái，屋根の墨】 : (1) - (1) '

2) 梁行, 桁行の各柱間寸法とチェンの位置 : (2) - (2) '

3）柱高さ（地盤面）と柱転び : (3) - (4) 
4）ケオの下端など各部材の形の描画

5）ドンタイ，桁行材の断面など

作図上，上記 1）と 2）は前後する場合もある．柱高さや地盤面に先 行して, 屋根勾配が描かれるのが特徵である，部材などの納まり，全体 のバランス等を確認した後に，ケオ，チェンは型板【Rập】を採り，柱 間, 柱高さ等の寸法は間笔に移して, 部材の加工に進む. 細部の手法に 違いは認められるが，フエ 4 組，ホイアン 1 組のいずれの大工棟梁も， 設計の手順はほぼ同様である. いずれも主な部材寸法は梁行架構の作図 をしながら調整を加えており，桁行架構の断面図によって柱，ケオなど の寸法を設計することはほとんど無い. 立面図に至っては作図の例が無 く, 梁行架構によって建築の全体性を把握していると思われる. 以下にその設計方法の要点を整理する.

\section{3-3. 屋根勾配}

フエの伝統家屋では, 腋尺【Thước Nách】と呼ばれる正三角形型の 大工道具が用いられる (写真 2 , 図 6 右上)。腋尺は一辺 1 尺 $(400 \mathrm{~mm})$ 程度の正三角形を為す道具で, 主に屋根勾配や矩を出すために使用する. 正三角形の底辺を $600 \mathrm{~mm}$ 程度として突き出した形のほか, 正三角形型, 底辺と垂線だけで構成される $\mathrm{T}$ 字型の計三種類の形が確認されている. フエで確認されている腋尺はいずれも一辺を $400 \mathrm{~mm}$ 前後, クアンナム 省では一辺が $430 \mathrm{~mm}$ 前後となっていることが確認されている.

腋尺を使用した屋根勾配の決定に重要な要素として図 6 の分割点 $\mathrm{t}$ が 挙げられる. 分割点 $\mathrm{t}$ は線分 $\mathrm{AB}$ を 3:97に内分して設定されており, 図 6 のように, 線分 C-t を転びを持つ柱心に合わせた際の直線 BC がケ オの背の線【Mực Lưng Kèo】となる. フエの伝統家屋ではケオの背に 母屋桁を直接載せるため, ケオの背の線が即ち屋根勾配の線となる. 図 6 の場合, 屋根勾配を「カップ・97」と称し, この数字が小さいほど勾 配は急となる.フエの Tân 氏によれば $95 \sim 99$ が一般的であり，屋根

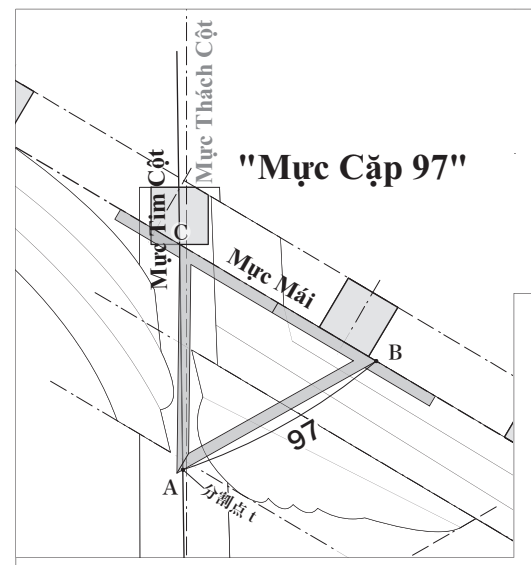

図 6 腋尺による勾配決定方法
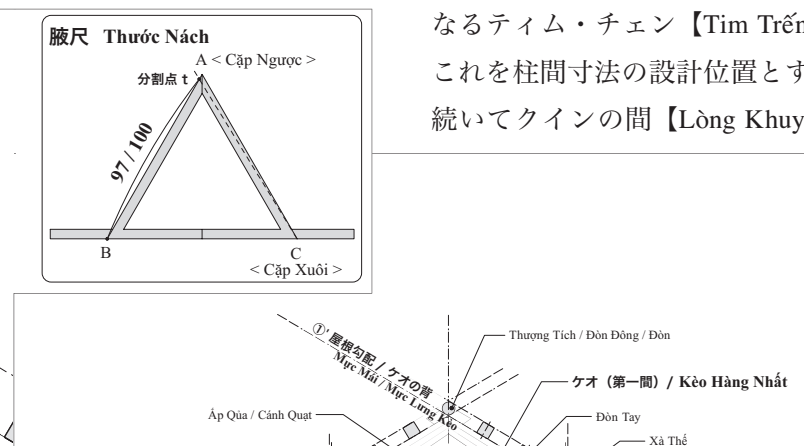
続いてクインの間【Lòng Khuyn】, クーの間【Lòng Cù】へと順次寸法

\section{3-4. 柱間寸法の決定方法}

(1) 柱間寸法の設計位置

梁行架構において柱間寸法を決定する際, 柱の内転びを前提とするた め，どの位置で柱間を定めるかが問題となる．フエおよびホイアンのケ オを主構造とした伝統家屋では梁行方向に柱元を固めるような設計上重 視すべき部材が無い. 梁行方向に設けられる建具は柱，ケオ，チェンに よって架構が固定された後に，その架構に合わせて設置してゆくのが通 例である. よって柱間寸法は, 重要な部材の無い柱元よりも, ケオ, チェ ン等の重要な部材の集中する上方で決めた方が設計上は有利である.

今回, 調査を行ったフエおよびホイアンの大工は, 5 組いずれもチェ ンの間【Lòng Trến】の寸法指定から始める ${ }^{20)}$. チェンの高さの基準と なるテイム・チェン【Tim Trến】(「チェンの心」の意) を水平に取り, これを柱間寸法の設計位置とする。この基準位置へ最初にチェンの間,

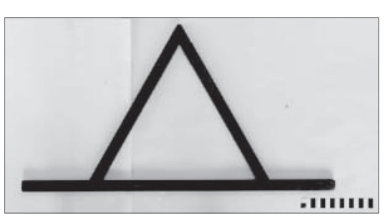

写真 2 中部の腋尺 トゥオックニャック

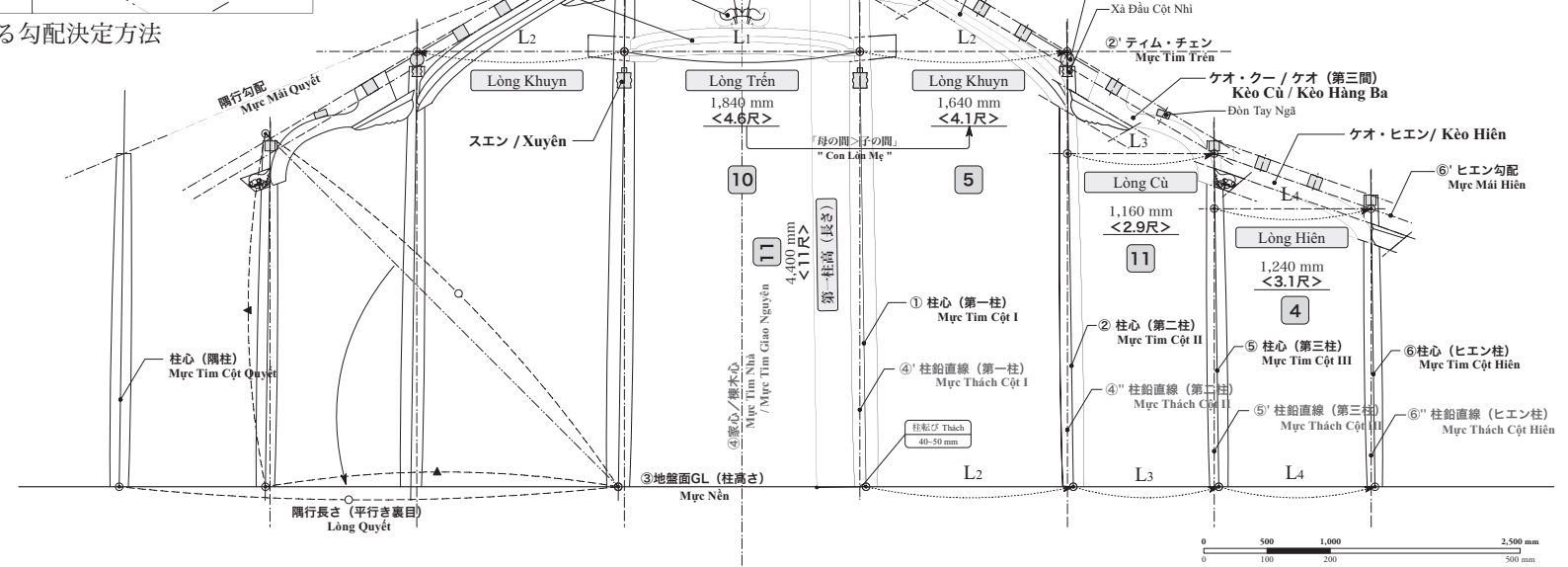

図 5 フエの伝統家屋の梁行断面設計の例 (Nguyễn Rê 氏による設計方法に基づき作図) 
を減じながら柱間寸法を配置する。ヒエンの間【Lòng Hiên】は架構が 両脇チャイの間に影響しないためか, あまり寸法上のこだわりは無く, 屋根勾配も含め, 任意に決める事が多い.

柱間寸法の設計位置となるティム・チェンの高さについては，その位 置決定方法にいくつかのルールがある.

<第二柱頂部での三種の位置 $>$

原則としてティム・チェンは第二柱の柱頂部に設けることが多い. 更 にその中にも図 7 の通り, 柱頂部に重なる2つの部材ドンタイ【Đòn Tay】, サーダウコット【Xà Đâu Cột】を挟んで三種の位置が認められて おり, ドンタイ上端をムック・ガック【Mực Gác】, 両部材の間を貫く場 合をムック・チェン【Mực Chen】, サーダウコット下端をムック・ロン 【Mực Lòn】と称する。柱高が低い場合はムック・ガック, 高い場合はムッ ク・ロンなどと使い分ける。柱高がかなり低い場合や上チェンー下スエ ンの場合などは，ムック・ガックの更に上にティム・チェンを置くこと が多い.

＜忌避すべき位置>

ティム・チェンを延ばした位置に部材や任意の点が当たってはならな い. 以下がフエの大工棟梁が言う忌避すべき位置である。

1. ドンタイを貫く【Hùynh Tử / Phạm Tử

2. ドンタイ間の中点を貫く【Phạm Trực】

3.「ケオの喉（ケオ・柱接合部の中心）」を貫く【Yết Hâu】

上記 3 に似た考え方で柱頂部とケオ下端の中点【Tim Họng Kèo】は避 けるという例も聞かれた。点を嫌うという点で 2 に近い. 例えば, フエの Thám 氏はドンタイを忌避しながら，ムック・チェンよりやや下， サーダウコットを貫く位置にティム・チェンを通すことは可能と考えて いる，延長線上の部材に注意する点は共通するが，その実際はある程度 の多様性があるのかもしれない。またホイアンの Tám 氏は第一柱頂部 からの実寸指定とし，ムックチェンなどに関しては未知であった。

さてこうしたルールに即して定められたティム・チェンの位置へ各柱 間の寸法を割り付けていくわけであるが，自ずと第二柱より外の間であ るクーの間, ヒエンの間などは, 柱間寸法の設計位置より低い位置とな るため，指定すべき任意の柱心を第二柱に平行に設けるなど，作図上は 副次的な扱いとなる。ここには第二柱までの梁行三間とケオで構成され る間を重視する姿勢が見られる，先述の通り,この三間を特に「家の間」 と呼ぶ，更にティム・チェンの位置で決められた梁行寸法はチェンの間 が最も重要視され，ティム・チェンと第一柱の交点は柱内転びの始点と なる。 また大工は家の規模を表す際にも柱間数などに加えて, チェンの 間の寸法を以て家の大きさを表現する。例えばチェンの間が 4.2 尺の家 屋の場合は「4.2家【Nhà 4.2】」と称すのが通例である.

(2) 十二直【Mười Hai Trực】

フエやホイアンの伝統家屋では各柱間寸法は梁行, 桁行ともに実寸指 定される. 5 組の大工いずれからも基準格子や比例などの考元方は聞か れなかった。実寸指定に際しては十二直（ホイアンでは魯班尺）による 数值の吉凶判断が決定因の一つとなっている.

十二直は日本でも用いられたことのある暦注の一つであり, 主に日取 りを占う体系である (図 8)。フ工の大工棟梁はこれを建築の寸法決定 に用いる，例えば指定したい柱間寸法が「4.1 尺」であるとする。この 数字を桁毎に「 $4+1 」$ と足し合わせ, 得られた「5」がこの寸法の十二 直の值となる。建築ではこれが $4 \cdot 5 \cdot 10 \cdot 11$ のいずれかであるのが望 ましい，住居は 4 か 5 , ディン, 祠堂，寺院は 10 か 11 , 宮殿などの更 に上級の建物は 9 が良いという話も聞かれた。

またチェンの間に比ベクインの間はやや減ずるのが原則である ${ }^{21)}$ が,
表 4 各大工棟梁の屋根勾配の決定方法

\begin{tabular}{l|l||l|l|l}
\hline $\begin{array}{l}\text { 大工棟梁 } \\
\text { Lê Kim Tân }\end{array}$ & TT Huế & Cặp 97 & Mực Tim Cột & 設計順序 \\
\hline Châu Văn Điền & TT Huế & Cặp 98 & Mực Thách Cột & 柱 $\rightarrow$ 屋根 \\
\hline Nguyễn Rê & TT Huế & Cặp 97 & Mực Tim Cột & 柱 $\rightarrow$ 屋根 \\
\hline Lê Viết Tám & Quảng Nam & Hết Thước(Cặp 100) & Mực Tim Giao Nguyên & 屋根 $\rightarrow$ 柱 \\
\hline Phan Trinh Thám & TT Huế & Cặp 100 & Mực Tim Nhà & 屋根 $\rightarrow$ 柱 \\
\hline
\end{tabular}

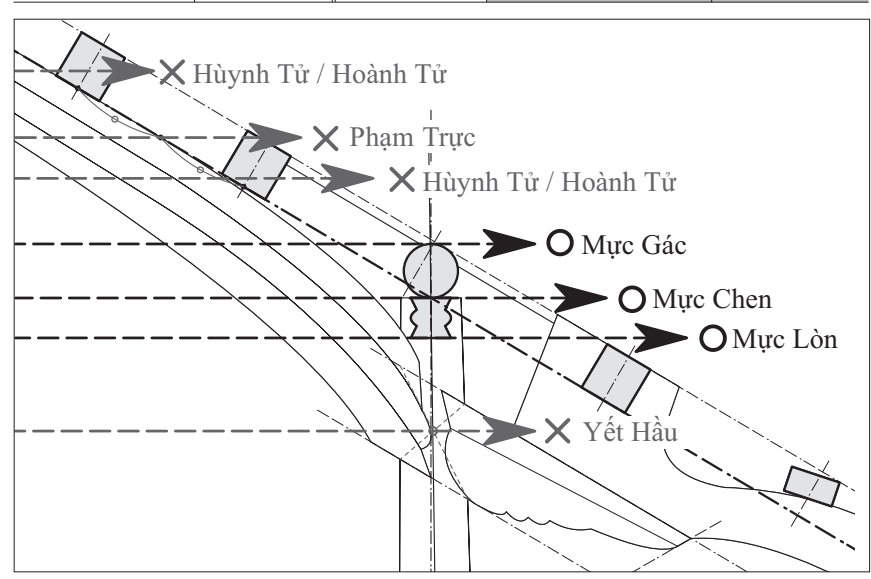

図 7 テイムチェンの位置

同時に双方の間で上記の十二直を得ることが望ましい，自ずとチェンの 間を十二直「5」か「11」となる寸法を決め, そこから 1 尺, 1 寸， 1 分のいずれかを落とすのが簡易な方法である，他方でチェンの間「4.24 尺 $=10 」$, クインの間 $\ulcorner 4.1$ 尺 $=5 」$ とう場合もある.

ただし，この吉凶判断法は三桁の数字まで考慮可能であり，また数が $\ulcorner 12 」$ を越えた場合の処置は更に二桁を足し合わせる場合とそこから 10 を減じて考える場合とどちらで考えても良いなど，その都度の都合に応 じられるやや緩やかな許容を持ったルールである ${ }^{22)}$. ホイアンの Tám 氏は魯班尺によって寸法の吉凶を占う。寸法に市販の魯班尺を当てるだ けの簡便な方法ではあるが，特にチェンの間の寸法が吉数であることに こだわるのはフエと同様である。 またフエの Thám 氏は十二直に更に自 前の八門尺 ${ }^{23)}$ を用い，両方で吉数を満たす寸法を選択する方法を採る.

3-5. 柱高さ（地盤面）と柱転び

十二直によって吟味された柱間寸法が割り付けられた後, 柱高さ（時 に長さ)と柱転びが決められる。柱間寸法に応じて垂線【Mực Thách Cột, 柱転びの墨】がティム・チェンから下ろされ, 柱元にて転びの長 さを採り, 外側へ開くように転びを設ける。この時, 地盤面を描く必要 があるが，屋根勾配の線との距離を採るだけであるから，一箇所で高 さを決めれば良い。第一柱の高さを基準に地盤面を決める場合が多く, 頭貫下端の始点を特にジャーサー【Dạ Xà】と呼ぶ。第一柱上に載るド ンタイは頭貫サーを兼ねている場合が多く，これをサーテー【Xà Thế】 と呼ぶ（図 9)。柱高の寸法もフエでは十二直，ホイアンでは魯班尺を 満たすように調整して実寸指定する。フエの Điền 氏は第二柱上の母屋 桁下端【Dạ Đòn Tay】を始点に柱高を採り, この点にティム・チェン, ケオの背の線, 第二柱心の 3 つの線が交錯するという状態を指して「三

\begin{tabular}{|c|c|c|c|c|c|c|c|c|c|c|c|}
\hline 十二直 & Mưò & ai Trực & & & & & & & & & \\
\hline 1 & 2 & 3 & 4 & 5 & 6 & 7 & 8 & 9 & 10 & 11 & 12 \\
\hline 建 & 除 & 満 & 平 & 定 & 執 & 破 & 危 & 成 & 収 & 開 & 閉 \\
\hline Kiến & Trừ & Mãn & Binh & Định & Chấp & Phá & Nguy & Thành & Thu & Khai & Bế \\
\hline \multicolumn{8}{|c|}{$\begin{array}{l}\text { Nhà ở } \\
\text { 住居 }\end{array}$} & $\begin{array}{l}\text { Cung Điện } \\
\text { 宮殿 } \\
\text { (最高位) }\end{array}$ & \multicolumn{2}{|c|}{$\begin{array}{l}\text { Đinhh / ディン } \\
\text { Chùa/ / 寺院 } \\
\text { Nhà Thờ / 祖㾰 }\end{array}$} & \\
\hline
\end{tabular}

図 8 柱間寸法決定に使用される十二直 
表 5 柱間寸法の決定方法

\begin{tabular}{|c|c|c|c|c|c|c|c|c|c|c|c|c|}
\hline \multirow[t]{2}{*}{ No. } & \multirow[t]{2}{*}{ 模型名 } & \multirow[t]{2}{*}{ 担当大工棟梁 } & \multirow[t]{2}{*}{ 地域 } & \multirow{2}{*}{$\begin{array}{l}\text { 尺度 } \\
1 \text { 尺長 } \\
\end{array}$} & \multirow[b]{2}{*}{ 脇尺長 } & \multirow[t]{2}{*}{ 寸法の判定 } & \multicolumn{5}{|l|}{ 柱間寸法 } & \multirow{2}{*}{\begin{tabular}{|l|} 
ティムチェンの高さ \\
Tim Trến 高さ \\
\end{tabular}} \\
\hline & & & & & & & Lòng Trến & Lòng Xuyên & Lòng Khuyn & Lòng Cù & Lòng Hiên & \\
\hline 01 & Nhà 4.2 & \multirow{3}{*}{ Lê Kim Tân } & \multirow{3}{*}{ TT Huế } & \multirow{3}{*}{$400 \mathrm{~mm}$} & \multirow{3}{*}{$403 \mathrm{~mm}$} & \multirow{3}{*}{ 十二直 } & 4.24 尺 & 6.5 尺 & 4.1 尺 & 2.62 尺 & (なし) & (第二柱より上 2 番母屋桁下) \\
\hline 02 & Nhà 3.8 & & & & & & 3.8 尺 & 6.23 尺 & 3.7 尺 & 2.44 尺 & (なし) & Mực Chen \\
\hline 03 & Nhà 3.2 & & & & & & 3.2 尺 & 6.8 尺 & 3.1 尺 & 2.26 尺 & (なし) & Mực Lòn \\
\hline 04 & Nhà 4.2 Vỏ Cua & Châu Văn Điền & TT-Huế & $400 \mathrm{~mm}$ & $400 \mathrm{~mm}$ & 十二直 & 4.2 尺 & 6.35 尺 & 4.0 尺 & 3.15 尺 & (Vỏ Cua) & Mực Chen \\
\hline 05 & Nhà 4.6 & Nguyễn Rê & TT-Huế & $400 \mathrm{~mm}$ & $400 \mathrm{~mm}$ & 十二直 & 4.6 尺 & 6.4 尺 & 4.1 尺 & 2.9 尺 & 3.1 尺 & Mực Gác \\
\hline 06 & Nhà $1.79 \mathrm{~m}$ & Lê Viết Tám & Quảng Nam & (mm実付) & $433 \mathrm{~mm}$ & 魯班尺 & $1870 \mathrm{~mm}$ & $2600 \mathrm{~mm}$ & $1700 \mathrm{~mm}$ & $1300 \mathrm{~mm}$ & $900 \mathrm{~mm}$ & (Dạ Xà 〜 Dạ Trính : 1050mm) \\
\hline
\end{tabular}

墨一接【3 Mực 1 Giáp】」として重要視している，他にフエの Rê 氏は柱 高さでは無く長さを採り，フエの Thám 氏は柱頂部で高さを採るなど, 方法に若干の差異が認められる.

このように決められた地盤面によって柱元の位置が決まり，そこで柱 転びを指定する，転びの数值は模型の場合はいずれも実寸指定で採られ ているが, フエの Tân 氏によれば柱高さの $0.7 \%$ 程度が良いという. 第二, 第三柱の転びはそれぞれ実寸指定する場合と，第一柱に平行とする場合 の大きく二種ある、転びの始点はフエでは第一柱をティム・チェンと柱 心の交点から,第二柱, 第三柱はドンタイ下端(柱頂部) からとしている. ホイアンの Tám 氏だけが作図上は第一柱も含めて全てドンタイ下端 (柱 頂部）から転ぶとした。彼の場合は部材仮組み時に改めて第一柱の転び をティム・チェンからへと調整する方法であり, 結果的にはティム・チェ ンから転ぶと考えて良い。また桁行方向へも両チャイの間の柱と脇柱筋 は内転びをする。よって隅の柱は四方転びとなるのが原則である.

また一度決められた柱高さ（地盤面）が梁行架構の設計・作図の最後 に，例えば軒先の高さ等を考慮して打ち直される場合も度々あり，また 加工の際に柱は若干長めに切り出して, 組み上げ直前の仮組時に柱元を 切り揃えるのが通例である。こうした場合は既に決められた柱転びを直 すことは無用であるため, 結果として設計時に指定した転びの数値は竣 工後にはあまり意味を成さない場合が多い. 水平方向の基準線は地盤面 であるよりも，むしろテイム・チェンであるという意識が強い.

3-6. ドンタイとサーテーの数え方

ドンタイやサーテーなどの垂木を受ける部材の数え方について, フエ では以下の四つの方法が確認された。

生直 $\mathrm{A}$ ：前第二柱上より後第二柱上まで [生 $\rightarrow$ 生］

生直 B：棟木脇ドンタイよりドンタイガーまで [生 $\rightarrow$ 老］

生直 $\mathrm{C}$ : 棟木より第二柱上まで $[$ 生 $\rightarrow$ 生 $]$

十二直 : 棟木から第二柱上のドンタイまで [建 $\rightarrow$ 成 $]$

生直（チュックシン【Trực Sinh】）による数え方とは「生老病死」の 四文字を「生」から順に当てながら, 総数の善し悪しを言う方法である. 図 10 に示したように, 例えば棟木を「生」と当て, 隣のドンタイを「老」, 更に次のドンタイを「病」という順に数え,「死」の次はまた「生」に戻つ て数え続ける. 生直の四字は仏教の四相に相当するが, 仏教上の教義と の関係は不明である。時に「良直【Trực Tốt】」と呼ばれることもあるから， 教義上の意味よりは字義と並びから吉凶判断の道具として見立てられて いるという印象を受ける ${ }^{24)}$. フエの Thám 氏からは十二直を使用する方 法も聞かれた。また L.Craste(1939) ${ }^{25)}$ に生直によるほぼ同じ数え方が 紹介されている.

いずれの数え方であれ, 第一ケオに三間, 第二ケオに五間, 第三ケオ (ケ オ・クー)に三間, ドンタイの間が設けられる結果となる点に注意したい. 前述の北部での言い方に倣えば「上 3 中 5 下 3 」となる。実遺構ではフ 工調査 1998 の実測対象 70 棟中 63 棟が「上 3 中 5 下 3 」となっている. またフ工阮朝王宮のほぼ全ての正殿遺構（凝禧殿を除く）で「上 3 中 5 」
となっており, 宮殿も含めて極めて画一的に数が意識されていたと解釈 できる．また上記の「生直 $\mathrm{B} 」 の$ 方法などは染意的とも言える数え方で ある. 経緯として始めに既に決まった本数があり，それに対して後に意 味付け，体系付けを行った結果と言えるかも知れない。 なおホイアンの Tám 氏によれば彼の場合は「上 2 中 4 下 $3 」$ とりう数が一般的という. Tám 氏の場合も生直を使用するが，フエと異なり軒先から「生」で始 め棟木で「生」, 更に後第三柱上まで「老」とするのが良いと考えている. フエと数は異なるが，これも始めに決まった本数があり怨意的に体系付 けが為された結果と考えて良いと思われる.

前述の通り, 北部のディンでは母屋桁の間隔が設計の一単位として取 り扱われた.フエおよびホイアンの伝統家屋(あるいは恐らく宮殿も)は, 家屋によって柱間の規模や派隇が比較的多様であるにも関わらず，母屋 桁の数が決まっているため, 自ずと母屋桁の間隔は柱間毎に代わること になる，また設計上も柱間が決まった後に等間割りを前提に調整して配 置されるから，柱間寸法と母屋桁間の距離に設計上の単位寸法という考 え方が介在しないと言つて良い.

\section{3-7. 中部の伝統家屋の設計技術の特徴}

以上述べてきたフエとホイアンの大工棟梁が持つ伝統家屋の設計技術 の特徵を以下にまとめる.

第一に屋根勾配の決定について，水平線を介すること無く，柱を基準 に正三角形の腋尺を以て直接決定する点が大きな特徴である。腋尺はケ オの勾配のみならず，ケオ木鼻の墨【Mực Cắt Đuôi Kèo】の描画にも用 いられ, ケオを持つ梁行架構が中部以南のベトナムで広範に分布するこ とを考えると，腋尺の使用も同様に広範な分布を示す可能性が高い。ま
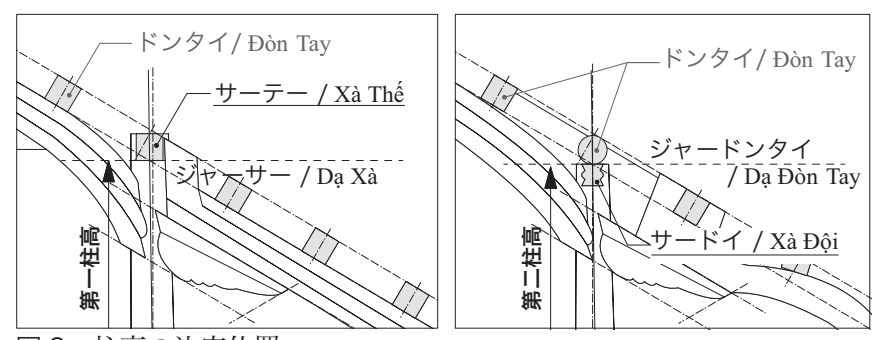

図 9 柱高の決定位置

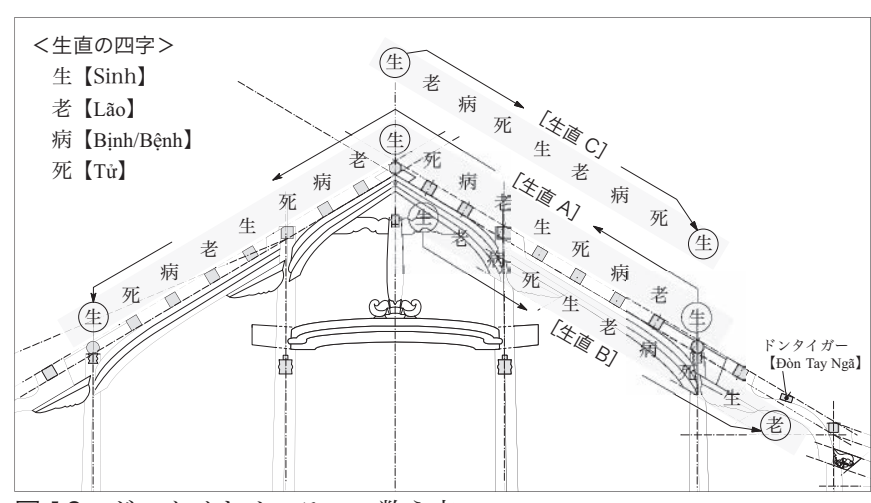

図 10 ドンタイとサーテーの数え方 
た正三角形を基本とする勾配は，鉛直方向の高さが勾配の為す斜辺に対 して $1 / 2$ とな関係が常に固定された勾配である。これは斜材とその高 さの関係が勾配を為す方法であると換言できる。登り梁と柱を主として 構成さ扎水平材の少ない中部の伝統家屋の梁行架構に相応しい勾配の制 御方法である，仮にこの「斜材 2 , 高さ $1 」$ とう長さの関係を重要視 する場合，それぞれに対応する部材があれば，その相互の部材長の把握 に多大な便宜があるが，斜辺に相当する登り梁ケオは長い木鼻が柱を貫 いて更に屋根勾配の墨から離れて下る形状を持ち，また棟木下の登り梁 ケオが合掌を組んでいるために棟持ちの柱も束も必要無く, 高さに相当 する鉛直の部材は重要視されない.つまり登り梁ケオと柱を中心に構成 される梁行架構は実際には斜辺と高さの利点を活かせるような関係にあ る部材を持たず，この利点を充分に発揮できない。例えば木鼻や合掌組 みを前提とせずに，架構が軸組と小屋組に二分でき，鉛直材と斜材を主 として水平材が圧倒的に少ない素朴な架構型式が，腋尺を基本とする設 計技術の原型として想定できるかもしれない. 非常に興味深い技法であ るが，現在の大工がこうした利点を積極的に活かすような知見を持たな い点は留意すべきであろう，今後も他の事例を加えて考察を進めていき たい.

第二に柱間寸法が十二直や魯班尺に基づいて吉数として調整された実 寸指定が行われる点．日本の木割に関する理解を前提に，対象とした全 ての大工棟梁へ柱径や柱間相互の比例関係についても確認したが，全体 を包括するような比例系統は存在しないようである ${ }^{26)}$. 吉凶にて数字 を加減する必要がある以上，結果的には実寸指定が避けられないのは必 至で，寸法相互に比例関係を設けることはより複雑で高度な体系が必要 となろう。単位寸法を用いる北部的な設計技術が確認されないのも当然 である，同様に屋根勾配の決定において水平線が介在しない以上，平面 計画寸法との関係性は全くないと言って良い. また吉凶判断の過程で概 念上は 110 寸まで問題にしているが施工の精度を考えれば，実際の竣工 後の建築にどれだけの意義が付与されるかは甚だ疑問である。例えば実 際の遺構から遺構尺を復元するような所作は非常に難しい.

第三に柱間寸法の設計位置の設定において第二柱頂部での位置が問題 にされる点。ティム・チェンの延長線が通る位置を考えながら設計を行 うということは，梁行架構の作図を前提にしながら実体の無い設計墨を 概念として強く意識する結果である。中点や部材を貫くことを忌避する などは，経験的に裏付けられた技術というよりは，むしろ吉凶を以て建 築に権威性を付与するための表面的な操作であり，技術的な意義は軽薄 である，その一方で技術的にはチェンの高さが比較的自由に設置できる という指摘も可能であろう。また梁行前後第一，第二柱の三間を「家の 間」と呼ぶ点を合わせて考えれば，この架構の祖型となった架構が前後 の第二柱頂部を三間分の横架材で結び，軸部と小屋組に二分できるよう な架構を持っていた可能性も考えられる ${ }^{27)}$.

第四に柱高の変更が可能な点．柱高が最終的に自由に変更が可能とい うことは，転びを含んだ柱元の柱間寸法の設計寸法の重要度が非常に低 いということである。同時に水平線の必要性は地盤面の他には唯一の梁 行水平材であるチェンに関わるのみであり, 他の部分は柱とケオを差し 掛ける形で構成されるから，一組ずつ二部材の関係が腋尺で保たれれば 良い。即ち第一間を除いては鉛直線も不要であるとさえ言えるだろう。 ここに改めて水平線, 鉛直線の重要性が希薄である状況が確認できる. 結果として, 梁行架構の制作においては部材加工や仮組みの作業工程が より重要となる。

第五に母屋桁の数え方について. 吉凶の判断を加えるのは一見すると 北部的なあるいは中国的な所作にも見えるが，その実，目指している数
は同じである、凶字を伴う数え方である以上は，覚え歌に留まらない意 味を有しているが, 数え方に幾つかの方法が見られるにも関わらずフエ の実遺構の大半が同じ数を持つ点から, 始めに決められた本数があり, 怨意的に吉字を当てたと考える方が妥当であろう。フエの多くの伝統家 屋で，宮殿に倣うかのように母屋桁が同じ数で配置される点は，権威性 を付与する意味が大きいかとも思われる。

\section{4. 北部と中部の設計技術の相異}

以上，述べてきた点より，北部と中部の梁行架構の設計技術の相異の 最も大きな要因は，屋根勾配の制御方法に求められる。

北部は水平材，鉛直材の多用を前提として，L 字型の道具を媒介に屋 根勾配と平面計画が関連づけられる設計技術に体系化された。中部では 水平材よりも登り梁を中心に据えた架構を前提に, 屋根勾配と柱心の墨 を直接結びつける道具として腋尺が生まれた。ここでは水平，鉛直に設 計墨が展開しないため，あくまで屋根勾配とそれに沿つた登り梁の制御 が設計の要点となる。水平材が少ないが故に，基準格子や単位寸法と いった発想が馴染まなかったとも言えるだろう。また腋尺は高さと斜辺 が $1 / 2$ の関係に固定される勾配を前提とするから，鉛直材と斜材を主構 造とした架構で最も活かされると考えられるが，現在の架構では充分に その利点が活かされていない. 現在の大工もこうした知見を持っておら ず，設計においてもそれを必要としない．現在見られる架構や技術を前 提に腋尺とその勾配制御方法が開発されるとは考元難く，その発生を促 すような異なる架構形式も想定すべきであろう.

北部の遺構で重姳梁に設けられるチュウ・ノンやダウ・センといつた 部材が母屋桁の直下を踏む点も, L 字型の道具による墨付けの体系に適 う方法と言える。またフエの宮殿建築では「重花柱架」と呼ばれる母屋 桁を重ね梁と束や斗との関連を思わせる部材で受ける架構があるが，夕゙ ウ・センに相当する部材が母屋桁を踏むことは無い.

北部の登り梁であるケーが屋根勾配と無関係に設計されることは，こ の部材が北部の本来の設計技術に馴染从が薄いことを示すと考える，中 部では登り梁ケオの背の線が始めに屋根勾配として設計され，ほぼ全て の墨がこのケオの背の線に関係する.

また設計技術上の関連性を考える時，水平材と L 字型尺を基本とす る北部と，ケオと腋尺を基本とする中部では相互の影響関係を認めるこ とは難しい，長い間全くの別の体系として相容れない状況であったとい う想像も可能であろう。本稿で採り上げた中部の設計技術では北部的な 要素はあくまでも表面的な意味づけに留まっており，技術的には根深い 相異が現在まで継承されている，このような技術面での地域間の相異に ついて，その背景を考える際，中南部が古代より近世まで広くチャム族 の地域であった歴史との関連が想起される。この点は今後も南部地域の 事例を加えて考察を進めていきたい.

\section{5. 結論}

以上述べてきた通り，北部と中部以南の設計技術の相異は，屋根勾配 の制御方法の相異にあるとまとめることができる，前者はあくまでも水 平と鉛直を設計の手がかりとした単位寸法を持つのに対し，後者は水平 と鉛直を設計上の拠り所とせず，且つ実寸指定とする．前者は水平距離 と高さで勾配制御するのに対して，後者は勾配斜辺と高さを $1 / 2$ の関係 に固定するという技術であった。この相異は北部の L 字型のトゥオッ クサームと中部の正三角形型の腋尺の相異であり，こうした各々の設計 技術の要を体現する道具の相異は，建築技術の埋めがたい断絶の証左で あると考えて良い 
熱帯研究で著名なフランス極東学院の P. Gourouによるベトナム中部 の伝統家屋の研究を筆頭に, 古都フエ友の会の L. Cadiere, A. Chapuis, L. Craste らによる 1910 年代から 1930 年代にかけてのフエおよびベトナ 厶中部の伝統家屋に関する報告は, 当時の伝統家屋の状沉を知る極めて 貴重な研究資料である。伝統家屋にまつわる風俗, 儀礼, 習慣などのほか, 代表的な家屋の形式，それぞれの形式に固有な名称についても触れられ ている，各論考で述べられた指摘は，いずれも当時のべトナムの農村や フエの文化・社会実態の把握に重点が置かれていると思われ，状沉の観 察と報告の域を出るものではないが，当時の農村における伝統家屋は大 半が茅惪きであった事実など，記録として貴重な情報を含んでいる。

2) Trần Thị Quế Hà 『べトナム・越族の伝統的木造民家に関する建築史的研究』 私家版, 東京都立大学学位論文, 2005.

3） 1997 年度〜 2002 年度までベトナム文化情報省が中心となり継続的に実 施されたベトナムの伝統家屋に関する総合調査. ベトナムの 10 省を対象 とし, 一次調査総数 4,287 件. 日越協働事業として行われ, 日本側参加 協力機関は昭和女子大学国際文化研究所を事務局とし，東京都立大学（当 時), 東京芸術大学, 千葉大学, 東京大学など.

4）大山亜紀子ほか「北部ベトナム仏教寺院の上殿の基本構成とその変化に ついて」『日本建築学会計画系論文集』第 576 号, pp.191-198, 2004.2, 大山亜紀子ほか「ベトナム北部における仏教寺院の前堂の変遷に関する 一考察」『日本建築学会計画系論文集』第 625 号, pp.689-694, 2008.3.

5）なお，伝統的木造建築に関するべトナム人による文献も多数あり，上記 の論文においてもいくつか採り上げられているが，管見の限り，建築遺 構の歴史を中心として，一般論としての建築の機能，性格等がまとめら れているに過ぎない，工学的な意味で建築技術を解明する視点を持ち且 つ前掲中 2）および 4）の論文の成果を上回る画期的な分析を伴う論文は 見あたらない，20 世紀初頭の仏人研究者によろ研究を焼き直しただけの モノも多い. 無論, 本研究で対象とする設計技術の解明という視座に基 づく研究は無く，本稿では中心的な参考文献としてとり挙げない 大凡 の理解として (1) 正確な実測図に基づいた分析，（2）設計に伴う各部寸法 決定の方法についての言及，(3) 設計の尺度に関する議論について，いず れもほとんど為されていない状況が当研究分野の水準を図るに足る。た だし（2）については Nguyẽn Khắc Tụng の著作に言及があり,後に触れる.

6) 本稿では実際の遺構分析による裏付けが決定的に不足しているが，現段 階では設計技術の概要を把握することを第一の目的とし，各実測遺構の 分析については以後の課題と考えている。よつて実遺構については現状 得られる情報としてQuế Hà，大山両氏の成果を適宜参照し，またそれぞ れの大工技術の信憑性については，大工個人の出自・経験，技術知識自 体の固有性のほか, 特に出自を異にする大工が同種の技術を保持してい る点を以てその裏付けとしたい。

7）北部の伝統木造建築では, 寺院やディン【Đình】などの大規模建築にお いて入母屋妻側へ梁行架構そのままではなく，別の架構を設ける例も確 認される。特に梁行にケーを用いた場合，入母屋妻側は重齐梁へと変更 する例がそれであるが，この場合も設計基準寸法は梁行とほぼ同寸であ ると予想される。

8）ディンはベトナム村落に見られる伝統的な大規模建築のひとつ. 現在も村 民の集会所等として機能していることが多い. その伝統的機能や意味につ いては，山田幸正ほか「ディンを集落社会の中核施設として行なわれる 伝統的祭礼について」『日本建築学会大会学術講演梗概集』F-2, pp.289290, 2006.9 などに詳しい.

9）レ・ヴァン・テー氏は八ノイ，ゲアン省等を中心に住宅，寺社，ディン を手掛けた後, 1997 年より現在までフエで阮朝宮殿の保存修復事業に参 加している、ディン・ヴァン・サーは彼の生家の至近にある。

10）ディン・ヴァン・サーはハーナム省リーニャン県にあり，17 世紀の創建 と言われる国家指定の文化遺跡，創建時期はあくまで伝聞であり，棟札， 銘文，文書等は未見である。柱頂部に大斗を設けて大梁を支持する型式 は大山 (2004) において A 型と称される 17 世紀初頭から見られる型式に 近いが，一方で母屋桁数は大山（2008）において 18 世紀末以降とされ る「梁行中央間 9 架」に相当する。近く解体修理の予定。

11）図中の基準線名称にある「ムック【Mực」とは「墨」の意

12）トゥオックサームは長尺で目盛りが無い直角の道具で, 底辺と垂線の基 準長さはその都度変更が可能であることを前提としている，現在まで北 部の Hà Bắc 省, Hà Nam 省, Hưng Yên 省, Hải Dương 省, Nam Định 省で その使用を確認している。 Thê 氏が底辺の基準単位を $100 \mathrm{~mm}$ としたこ とは，彼の制作上の便宜もあったかと思うが，基準単位に基づいた制作 手順に影響は無いと考え，ここでは彼の意図を尊重した。トゥオックサー ムについて詳しくはレ・ヴィン・アンほか「トゥオックサームについて

ヴィエトナム・フ工阮朝王宮の復原的研究（その 129）」『日本建築学 会大会学術講演梗概集』F-2, pp.171-172，2007.8 参照.

13）既に大山（2008）において，母屋桁数の比と柱間寸法の比がほぼ同じに なる点を以て「母屋桁間の距離が柱間寸法の基本単位であった可能性も ある」という指摘がある。ここではチア・コハンの寸法がいくらかを示
す意図もあり，同論文の数值に基づいて表を再構成した。

14）越語では "Thượng tứ - Hạ ngũ". 棟木を中心に梁行架構を半分に割って, 母屋桁間を数える。 大山 $(2004,2008)$ で扱われた仏教寺院では，この 事例に当たる遺構は 35 例中 3 例のみで，他は「上三下三」「上三下四」 あるいは「上四下四」が多い

15) Nguyễn Khắc Tụng, Nhà ở Cổ Truyền Các Dân Tộc Viêt Nam, Hội Khoa Học Lịch Sử Việt Nam, Trung Tâm Nghiên Cứu Kiến Trúc - Đại Học Kiến Trúc Hà Nội, Tập I, 1994, pp.54-58. 北部 Vĩnh Phú 省 Sông Thao 県と Yên Lạc 県の大 工から聴取した技術と述べられている。文中では母屋桁数との関連には あまり触れられておらず，あくまで事例として柱間に比例的な関係が見 られる点を重視している。

16）Trần Thị Quế Hà，山田幸正「第 3 章 バクニン省の伝統的民家」『ベトナ 么伝統住居の保存と再生』国際文化研究所紀要 Vol.5，昭和女子大学国際 文化研究所, 2000.3, p.20. 本稿では Vũ Tam Lang, Kiến Trúc Cổ Việt Nam, Nhà Xuất Bản Xây Dưng, 1999.9 の記述として引用しているが内容から判断して, 前掲註 15 からの転用と思われる。

17）前掲 Quế Hà (2005）pp.159-161 に 2 種類の架構型式を持つ北部の伝統 家屋について事例と共に中央間と脇間の空間序列に関する分析がある。

18）前掲註 3）の総合調查事業で作成された実測図面を使用、フエでは 1998 年に 70 件の伝統家屋に関して実測図面が作成されている. Nhà Rường は 68 件, 町屋が 2 件. フエの調査は主にフエ遺跡保存センターとフエ大学 が実測を行っている. 実測值は $\mathrm{cm}$ 単位で採られたと思われる数值も多く, 実測調査に不慣れと思われる作図もあり，これに基づいた設計寸法分析 は難しい. 主に架構型式の種類や部材数を把握するために使用した.

19）これまでに確認されている腋尺の種類や使用法については，レ・ヴィン・ アンほか「腋尺について (I) ヴィエトナム・フ工阮朝王宮の復原的研究 (そ の 125)」『日本建築学会関東支部 2006 年度 研究発表会 研究報告集 II』 pp. 385-388, 2007.3. およびレ・ヴィン・アンほか「腋尺について (II) ヴィ エトナム・フエ阮朝王宮の復原的研究（その 135）」『日本建築学会関東 支部 2007 年度 研究発表会 研究報告集 II』pp. 301-304，2008.3.に報 告している.

20）ホイアンの大工はチェンをチン【Trính】と称したが，同じ部材と見なせ るため，ここでは説明の便宜から全てチェンとして説明した。

21）「中央間が脇間より大きい」という意味で「コン・ロン・メー【Con Lòn Mẹ】(母は子より大きい)」という言葉がある

22）複数桁の数を桁毎に足してその数字の善し悪しを占うという方法は，心 トナムでは比較的庶民的な発想であり，例えば現在でも車両登録番号な ぞはその範疇にある。

23）市販の魯班尺に比して長さと文字の配置に相異がある，使用法は同じ。

24）生直によって母屋桁を数えるという方法は現在でもフエでは比較的有名 な方法らしく，棟瓦壁造の現代住宅でも屋根を架ける際には同じように 数を決めることがある

25) L.Craste, "Etude sur L'habitation Annamite a Hué et dans les environs", B.A.V.H., 1939-No.1, pp.21-42. なお Craste は「Sanh, Tật/Lão, Bệnh/Bịnh, Tử」の四字で数えるとしている.

26）部材の断面寸法については続稿にて詳報の予定である. 5 寸断面，4 寸断 面，3 寸断面などの選択肢があり，基本的には規模に応じてそれらを選択 して利用するという方法を採る。例えば「中ノ間十分一」というような 比例関係は存在しない,

27） Quế Hà (2005) において北部 4 省で梁行前後の第二柱頂部を三間分の横 架材で結ぶ架構型式が「II 型」として報告されているほか, 中部でも棟持 ち柱を持つ「Nhà Rội」と呼ばれる型式で前後の柱を結ぶ横架材を持つ事 例が報告されている. また L.Craste(1939)では「Nhà Rội」の同様の型式が 図示され，更に「Nhà Thượng Rường」と呼ばれる型式で前後の柱を結ぶ 横架材を持つ事例が報告されている。「Nhà Thượng Rường」は第二柱頂部 の横架材の上を梁行三間，下を梁行二間とした形式で，L.Craste 自身，非 常に稀な型式であると述べており，管見の限り実例は現存しない.

なお本稿は，平成 19 年度・文部科学省科学研究費補助金（若手研究 A）「フ エの伝統家屋の設計方法と建築技法 - 失われつつある伝統的技術の記録 -」(研 究代表者・林英昭)，日本学術振興会科学研究費補助金 (基盤研究 S)「阮朝王 宮の歴史的環境の復原-CG 技術を活用した再現と GIS 構築-」( 研究代表者・ 中川武) および文部科学省補助事業・私立大学学術研究高度化推進事業 (学術 フロンティア推進事業) 「ユネスコ世界遺産・フエの建造物群とその環境の保 全及び宮廷音楽等無形文化遺産の保護・振興」(研究代表者・中川武) の成果 の一部である. また本研究成果の一部は早稲田大学理工学研究所・プロジェク 卜研究「ユネスコ世界遺産「フエの建造物群」の学術情報の保存・管理と I C T基盤の構築支援」の一環として行われたものである. 現地においては，トゥ アティエン・フエ省人民委員会および省立フエ遺跡保存センター所長 Phùng Phu 氏の要請を受け協同学術調査が行われた。 また本文中の北部寺院の実測調 査成果については日本大学重枝豊准教授，大山亜紀子女史に，フエの伝統家屋 の実測調査成果については昭和女子大学友田博通教授, 首都大学東京山田幸正 教授に，快く使用の許可を頂いた。記して謝意を表する. 